Jurnal Info Kesehatan

Vol.17, No.2, December 2019, pp.88-100

P-ISSN 0216-504X, E-ISSN 2620-536X

DOI: 10.31965/infokes.Vol17.Iss2.292

Journal homepage: http://jurnal.poltekeskupang.ac.id/index.php/infokes

RESEA R C H

\title{
Path Analysis of the Effect of Biological and Social Factors on the Case of Breast Cancer
}

\author{
Nunik Ike Yunia Sari ${ }^{1 a^{*}}$, Estin Gita Maringga ${ }^{1 \mathrm{~b}}$, Wuri Widi Astuti ${ }^{\text {c }}$ \\ ${ }^{1}$ Stikes Karya Husada Kediri, Indonesia \\ a Email address: agharda1502@gmail.com \\ b Email address: estin.gita@gmail.com \\ c Email address: wuriwidi@gmail.com
}

Received: 31 October 2019 Revised: 26 December 2019 Accepted: 26 December 2019

\begin{abstract}
Breast cancer is the number one cancer as the cause of death in women in developed and developing countries. Breast cancer has the highest case in women in 161 countries. The objective of this study is to analyze the influence of biological and social factors on breast cancer cases in the Public Hospital of Kediri, East Java. The research design was analytic with a retrospective cohort approach. The research sample of 105 respondents used simple random sampling. Data collection was with medical records in January-December, 2017. Data analysis used the path analysis test. The test results obtained breast cancer is influenced by a history of hereditary breast cancer $(b=0.17, p=0.001)$; menopause age $(b=0.17, p=0.001)$; family planning history $(\mathrm{b}=0.11, \mathrm{p}=0.014)$; parity $(\mathrm{b}=0.08, \mathrm{p}=0.031)$; age $(\mathrm{b}=0.21, \mathrm{p}=0.001)$; income $(\mathrm{b}=0.21$, $\mathrm{p}=0.001)$. Parity was influenced by income $(\mathrm{b}=0.45, \mathrm{p}<0.001)$. The age of menopause was influenced by a history of hereditary breast cancer $(b=0.31, p<0.001)$; family planning history $(b=0.13, p=0.13)$; and age $(b=0.10, p=0.01)$. It can be concluded that the case of breast cancer was directly influenced by hereditary cancer, family history of birth control, age, parity, menopausal age, and income. Also, breast cancer was indirectly affected by income through parity; and hereditary history of breast cancer, family planning history, and age through menopause.
\end{abstract}

Keywords: Breast cancer, biological factors, social factors, path analysis

\author{
*Corresponding Author: \\ Nunik Ike Yunia Sari \\ Stikes Karya Husada Kediri, \\ PLK III Street, No. 19, RT. 01, RW. III, Bogokidul Village, Plemahan, Kediri, East Java, Indonesia. \\ Email: agharda1502@gmail.com
}

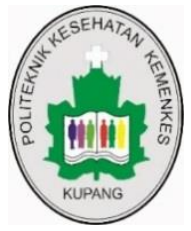

(CThe Author(s) 2019. This article is distributed under the terms of the Creative Commons Attribution 4.0 International License (http://creativecommons.org/licenses/by/4.0/), which permits unrestricted use, distribution, and reproduction in any medium, provided you give appropriate credit to the original author(s) and the source, provide a link to the Creative Commons license, and indicate if changes were made. The Creative Commons Public Domain Dedication waiver (http://creativecommons.org/publicdomain/zero/1.0/) applies to the data made available in this article, unless otherwise stated. 
Sari, N. I. Y., Maringga, E. G., \& Astuti, W. W. (2019). Path Analysis of the Effect of Biological and Social Factors on the Case of Breast Cancer. JURNAL INFO KESEHATAN, 17(2), 88-100. https://doi.org/10.31965/infokes.Vol17.Iss2.292

\section{INTRODUCTION}

Breast cancer is a malignancy in breast tissue originating from the ductal epithelium or lobules. Breast cancer is a number one cancer as a cause of death by cancer in women in developed and developing countries (Kemenkes RI, 2017).

Breast cancer has the highest case in women in 161 countries and causes death for women due to cancer in 98 countries (Fitzmaurice et al., 2015). In 2012, there were 1.7 million women diagnosed with breast cancer, and since 2008 the case of breast cancer has increased by more than $20 \%$ and $14 \%$ of them who have died. In 2012, there were 522,000 cases of death in women due to breast cancer (WHO, 2013). The case of breast cancer in developing countries is an average of 40 per 100,000. The case of breast cancer in the United States is 92 per 100.00 with a fairly high mortality rate of 27 per 100,000 or $18 \%$ of deaths experienced by women (WHO, 2018). Meanwhile, in Indonesia, the case of breast cancer is 12 per 100,000 and $80 \%$ of them come to health facilities with the condition of cancer that is in an advanced stage (Kemenkes RI, 2015)

Risk factors for breast cancer case include a woman's age over 50 years, a family history and genetics as carriers of the BRCA1, BRCA2, ATM or TP53 (p53) gene mutation, a history of previous breast disease (DCIS in the same breast, LCIS, high density in mammography), history of early menstruation ( $<12$ years) or slow menarche (> 55 years), reproductive history (no children and no breastfeeding), hormonal, BMI, alcohol consumption, history of chest wall radiation, environmental factors (Kemenkes RI, 2017). According to Rasjidi (2010) the main risk factors associated with the case of breast cancer are hormonal conditions and family genetic history.

Based on the results of the study (Anggorowati, 2013) in Kudus District Hospital, there were risk factors that significantly influenced the case of breast cancer including BMI, age at birth of the first child, history of breastfeeding, and age of menarche. The results of another study from Laamiri et al., (2015) showed that the prevalence of cervical cancer in women over the age of 45 is influenced by risk factors for menopausal age, a history of pill use, and a family history of breast cancer. The results of other studies about risk factors associated with the case of breast cancer are family history of breast cancer and physical activity/sports (Yulianti et al., 2016).

Preliminary studies conducted at the Public Hospital of Kediri in February 2018 found 83 cases of breast cancer in 2017. The case of breast cancer in Kediri Regency is still high, so that in the future, a preventive effort is required that can be done independently to prevent breast cancer. One of the efforts that can be done is by reducing some risk factors for breast cancer, one of which is by knowing the biological and social factors that influence directly or indirectly on the case of breast cancer through path analysis. Path analysis is one method of analysis that is different from existing research that can be used to solve these problems. This direct and indirect influence from biological and social factors can make a woman wiser in maintaining her health. This background encourages the importance of research on "The Path Analysis of the Effects of Biological and Social Factors on the Case of Breast Cancer."

\section{RESEARCH METHOD}

This study used analytical research designs with a retrospective cohort approach. The time of the study was from 27 of August to 17 of September 2018, at the Public Hospital of Kediri. The population in this study was all women who came to the Polyclinic in Kediri Regency Public Hospital in 2017 as many as 356 cases. The sample in this study was a portion of the entire population that met the inclusion criteria, which 
included women who came to the Polyclinic Surgery at Kediri Public Hospital, had breast lump complaints, period 1 of January-31 of December 2017. Meanwhile, the exclusion criteria were incomplete medical record data. Sampling in this research used simple random sampling that is 105 samples. The research variables consisted of exogenous and endogenous variables. Exogenous variables, consisting of a history of hormonal birth control, age, history of Ca descent, and income. Endogenous variables consist of parity, menopausal age, and breast cancer case. Data was collected using medical records to obtain general and special characteristic data which was recorded in the instrument data collection sheet. The collected data was then analyzed using path analysis.

\section{RESULTS AND DISCUSSION}

Table 1. Characteristics of respondents based on their latest education, age of respondent, history of hormonal birth control, history of hereditary cancer, income level, parity, age of menopause and breast cancer case.

\begin{tabular}{llrr}
\hline Characteristics & Criteria & n & $(\boldsymbol{\%})$ \\
\hline Education & Medium & 94 & 90.0 \\
\hline Respondent age & High & 11 & 10,0 \\
\hline & $<20$ years and > 35 years & 56 & 53,3 \\
\hline Planned family history & $20-35$ years & 49 & 46,7 \\
\hline & Hormonal & 68 & 64,8 \\
\hline Hereditary cancer & Non hormonal & 37 & 35,2 \\
\hline & Have history & 42 & 40,0 \\
\hline Income level & Nothing & 63 & 60,0 \\
\hline & $\leq$ Rp. $1.456 .000,-$ & 53 & 50,5 \\
\hline Parity & $>$ Rp. $1.456 .000,-$ & 52 & 49,5 \\
\hline & $<2$ & 56 & 53,3 \\
\hline Menopause age & $>2$ & 49 & 46,7 \\
\hline & $\geq 55$ years & 47 & 44,8 \\
\hline Case of breast cancer & $45-55$ years & 58 & 55,2 \\
\hline & Suffer & 47 & 44,8 \\
\hline
\end{tabular}

Based on table 1, it can be concluded that from 105 research subjects, $90 \%$ had secondary education; $53.3 \%$ aged $<20$ years and $>35$ years; $64.8 \%$ have a history of hormonal birth control; $60 \%$ have no history of hereditary cancer, $50.5 \%$ have income Rp. $1.456 .000 ; 53.3 \%$ had parity $<2 ; 55.2 \%$ experienced menopause at the age of $45-55$ years and $55.2 \%$ had breast cancer.

Table 2. Bivariate Analysis of the Effects of Biological and Social Factors on the Occurrence of Breast Cancer

\begin{tabular}{lrr}
\hline Independent Variable & r & \multicolumn{1}{c}{$\boldsymbol{p}$} \\
\hline Respondent age (years) & 0.21 & $<0.001$ \\
\hline History of Hormonal Family Planning & 0.11 & 0.014 \\
\hline Hereditary cancer & 0.17 & $<0.001$ \\
\hline Family income per month (Rupiah) & 0.41 & $<0.001$ \\
\hline Parity & 0.08 & 0.031 \\
\hline
\end{tabular}


Sari, N. I. Y., Maringga, E. G., \& Astuti, W. W. (2019). Path Analysis of the Effect of Biological and Social Factors on the Case of Breast Cancer. JURNAL INFO KESEHATAN, 17(2), 88-100. https://doi.org/10.31965/infokes.Vol17.Iss2.292

Menopause age (years)

0.17

$<0.001$

Table 2 shows that the respondent's age, history of hormonal contraception, hereditary cancer, family income, parity, and age of menopause had a positive effect on cancer case and were statistically significant $(<0.05)$.

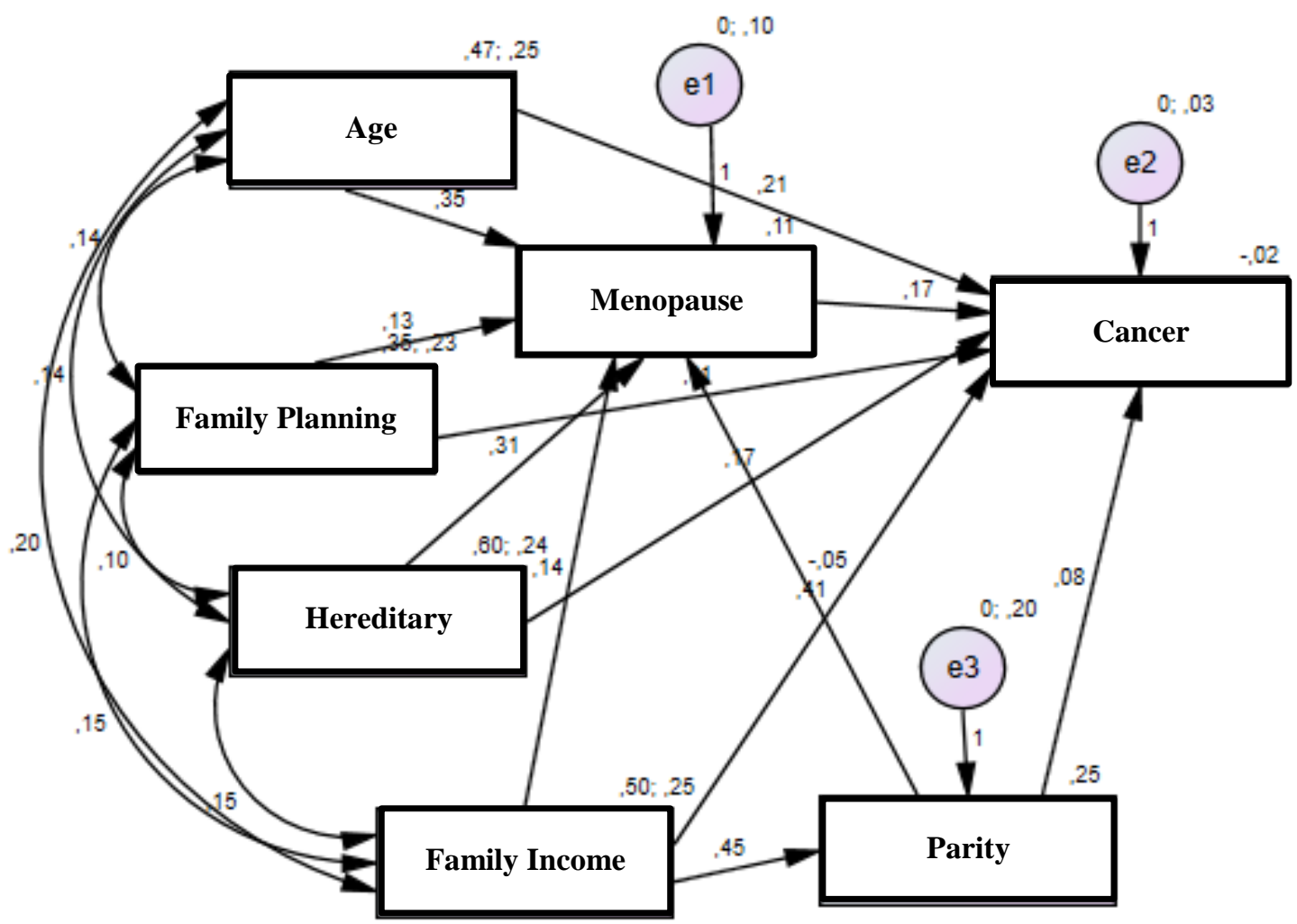

Figure 1. Structural model of path analysis.

Figure 1 shows the structural model after estimation, so the values in the figure are obtained. Indicators that show the suitability of the path analysis model, such as tabel 3 also indicate the existence of a goodness of fit model (measurement of model compatibility) found that the fit index result of CMIN is 4.67 with $\mathrm{p}=0.197>0.05$; $\mathrm{NFI}=0.99 \geq 0.90$; CFI $1.00 \geq 0.95$; RMSEA $=0.00 \leq 0.08$ which means that the empirical model meets the specified criteria and is stated in accordance with empirical data.

Tabel 3. Path Analysis Results

\begin{tabular}{llrrrr}
\hline Endogent Variable & Exogent Variable & b* $^{*}$ & SE & P & $\boldsymbol{\beta}^{* *}$ \\
\hline Direct Effect & & & & & \\
\hline Breast Cancer & $\longleftarrow$ Hereditary cancer & 0.17 & 0.04 & $<0.001$ & 0.17 \\
\hline Breast Cancer & $\longleftarrow$ Menopause age & 0.17 & 0.04 & $<0.001$ & 0.17 \\
\hline Breast Cancer & $\begin{array}{l}\longleftarrow \text { Planned family } \\
\text { history }\end{array}$ & 0.11 & 0.04 & 0.014 & 0.10 \\
\hline Breast Cancer & $\longleftarrow$ Parity & 0.08 & 0.03 & 0.001 & 0.08 \\
\hline
\end{tabular}




\begin{tabular}{|c|c|c|c|c|c|}
\hline Breast Cancer & $\longleftarrow$ Age & 0.21 & 0.05 & $<0.001$ & 0.21 \\
\hline Breast Cancer & $\longleftarrow$ Income & 0.41 & 0.05 & $<0.01$ & 0.41 \\
\hline \multicolumn{6}{|l|}{ Indirect Effect } \\
\hline Parity & $\longleftarrow$ Income & 0.45 & 0.87 & $<0.001$ & 0.45 \\
\hline Menopause Age & $\longleftarrow$ Income & 0.14 & 0.12 & 0.24 & 0.14 \\
\hline Menopause Age & $\begin{array}{l}\longleftarrow \text { Planned family } \\
\text { history }\end{array}$ & 0.13 & 0.09 & 0.13 & 0.12 \\
\hline Menopause Age & $\longleftarrow$ Hereditary cancer & 0.31 & 0.08 & $<0.001$ & 0.31 \\
\hline Menopause Age & $\longleftarrow$ Parity & 0.48 & 0.07 & 0.49 & 0.05 \\
\hline Menopause Age & $\longleftarrow$ Age & 0.35 & 0.10 & 0.01 & 0.35 \\
\hline \multicolumn{6}{|l|}{ Fit Model } \\
\hline $\mathrm{CMIN}=4,67$ & $p=0,197(>0.05)$ & & & & \\
\hline$=0.99$ & $(\geq 0.90)$ & & & & \\
\hline$=0.99$ & $(\geq 0.90)$ & & & & \\
\hline$=1.00$ & $(\geq 0.95)$ & & & & \\
\hline RMSEA $=0.00$ & $(\leq 0.08)$ & & & & \\
\hline
\end{tabular}

From table 3, it can be seen that the case of breast cancer is directly affected by hereditary cancer, family planning history, age and income. Each increase in one unit of hereditary cancer will increase the case of breast cancer by 0.17 units. Each increase in one unit a history of hormonal birth control will increase the case of breast cancer by 0.11 units. Each increase of one unit of non-reproductive age will increase the case of breast cancer by 0.21 units. Any increase in one unit of low family income will increase the case of breast cancer by 0.41 units.

Parity is influenced by income. Each increase of one unit of high income will increase parity by 0.45 units. Each increase of one unit of low parity will increase the case of breast cancer by 0.08 units. The menopausal age is influenced by a history of breast hereditary cancer history, family planning history, and age. Every increase of one unit of hereditary breast cancer will increase the age of menopause by 0.31 units. Every increase of one unit of history of hormonal birth control will increase the age of menopause by 0.13 units. Every increase of one unit of age that increases will increase the age of menopause by 0.35 units. Every increase of one unit of menopause age that is slow will increase the case of breast cancer by 0.17 units.

1. The positive influence of age on the case of breast cancer.

Based on the results of the study above, there is a positive influence of age with menopause age, which obtained a regression coefficient (b) of 0.35 with asymp.sign (p) is $0.01<0.05$ otherwise significant. Based on research results Diniyati (2016) stated that there is a significant relationship between age and the case of menopause, with a $p$ value $=0.005$. Age is related to the age of menopause, it is caused by the number of follicles in the ovaries of a woman will begin to decrease when the number is 25,000, and it occurs at the age of 37-38 years. Loss of follicles is caused by an increase in FSH levels that are not visible but are real and there is a decrease in inhibin.

Age is related to the age of menopause, it is caused by the number of follicles in the ovaries of a woman will begin to decrease when the number is 25,000 , and it occurs at the age of 37-38 years. Loss of follicles is caused by an increase in FSH levels that are not visible but are real and there is a decrease in inhibin. The accelerated loss of the 
follicle is caused by a secondary effect on the stimulation of increased FSH, which reflects a decrease in the quality and capability of aging follicles, and a decrease in inhibin secretion of granulosa cell products that produce a negative feedback effect on FSH secretion by the pituitary gland. It is likely that both inhibin-A and inhibin-B play a role, because the levels of inhibin-A and inhibin-B in the luteal phase decrease with advancing age and precede the increase in FSH (Diniyati, 2016).

An increase in FSH is related only to a decrease in inhibin-B, in response, the concentration of estradiol increases slightly. Decreased production of inhibin can either reflect a reduction in the number of follicles or a decrease in the capacity function of the older follicles or both. Decreased inhibin secretion by ovarian follicles occurs around the age of 35 years, but becomes fast after the age of 40 years (Diniyati, 2016). Under these conditions, age has a relationship with the age of menopause.

Based on the results of the study, the age of menopause with the case of breast cancer obtained a positive effect with a regression coefficient (b) of 0.17 with asymp.sign (p) was $0.00<0.05$ otherwise significant. The results of this study are supported by the results of the study of Laamiri et al (2015) that stated the slow menopause age of $>55$ years has a relationship to the case of breast cancer $(\mathrm{OR}=2,360$, $95 \%$ CI 1,$911 ; 2,914)$ this is thought to be caused by hormonal production in the ovaries that too long in women who experience slow menopause. The statement is also in line with the results of Anggorowati's research (2013) which showed that there is a significant relationship between menopausal age and the case of breast cancer, this is due to earlier menstrual age and late menopause associated with estrogen and progesterone exposure in women who are effect on the process of tissue proliferation in the breast.

Exposure to estrogen both exogenously with TSH and endogenously such as late menopause can increase exposure to estrogen longer in a woman's body, so this is risky to cause breast cancer, besides this risk can also increase if the menopausal woman has BMI is more than the normal limit, then the adipose tissue in body fat will convert androgens to estrogen (Suparman, 2014).

Based on the results of the study above, the relationship between age and the case of breast cancer has a regression coefficient (b) of 0.41 with an asymp.sign (p) value of $0.001<0.05$ otherwise significant. The results of this study are in line with the results of Awaliyah et al., (2017) research that there is a significant relationship between age and the case of breast cancer $(\alpha=0.0001)$, where as a woman's age increases, there is a 2.18 times risk of developing breast cancer compared to women who have breast cancer 2029 years old.

$60 \%$ of breast cancer case found in women aged $>60$ years. The greatest risk is found in women> 75 years. The results of another study conducted by Kallel et al., (2015) stated that, the average case of breast cancer occurred at the age of 31.7 years. Data obtained from the American Cancer Society (2017) displayed that the case of breast cancer in the range 2010-2014, occurs in women aged 62 years, whereas in black women the average case of breast cancer at age 59 years.

The results of another study, by Sihombing (2014) stated that breast cancer patients are mostly in the range of 41-50 years, this is in accordance with the theory that breast cancer began to develop rapidly at the age of 40-49 years before women entered the age of 50 years and over, while the risk of breast cancer itself develops until the age of 50 years and over with a ratio of 1 chance among 50 women. 
2. Positive influence of menopause age on breast cancer case.

The results of this study indicate that there is a positive influence of menopause age on breast cancer case that is directly, with a regression coefficient (b) of 0.17 with an asymp.sign ( $\mathrm{p}$ ) value is $0,00<0.05$ was considered significant.

According to Listywardhani et al., (2018) a woman's age when entering menopause has an influence on the case of breast cancer, this is due to the longer a woman enters menopause, the longer the body will be exposed to the estrogen hormone. High levels of the estrogen and progesterone hormones will trigger the development and change of the breast glands which have various hormone receptors. Estrogen exposure will increase the factors of cell proliferation and if it is not controlled biologically it will develop into cancer following its stages.

The results of other studies that are in line with the research above states that a woman's age when entering menopause for longer will have a greater risk for developing breast cancer. Onset of late menopause, every year will have a risk for breast cancer by $3 \%$, and any delay in the onset of menopause age every 5 years will have a greater risk for developing breast cancer, which is 17\% (Ford D et al., 1998 dalam Shah $\mathrm{R}$ et al. 2014).

3. The positive effect of family history of breast cancer on the case of breast cancer.

The results of this study indicate that there is a positive effect on family history of menopause that is directly, with a regression coefficient (b) of 0.13 with an asymp value.sign ( $p$ ) is $0.13>0.05$ was declared not significant.

The results of the above study, in line with the research results of Maringga et al., (2017), there is a significant relationship between the history of family planning use with menopause age $(b=0.29, \mathrm{SE}=0.12, \mathrm{p}=0.014)$. Based on the results of Bentzen (2012), study, the longer a woman uses hormonal type of contraception, it will reduce the number of Antral Follicle Count (AFC) and ovarian volume, as well as increase levels of Anti Mullerian Hormone (AMH) significantly, which means this condition will prolong the menopause age in a woman.

Research conducted by Fitriyani (2013), that women with a history of using oral combined pills will be at a small risk of 0.90 times to experience early menopause when compared with women who have never used oral combined pills. This condition is caused the body will be continuously exposed to the hormones estrogen and progesterone, so that it will affect the pituitary gland not to produce estrogen and progesterone which will cause menopause to be a long age.

Other research conducted by Laamiri et al., (2015), stated that the case of breast cancer in women over the age of 45 is influenced by a history of pill use and family history of cancer.

The results of the above study indicate that the age of menopause has a positive effect on the case of breast cancer with a regression coefficient (b) of 0.17 with asymp.sign (p) is 0,000<0.05 expressed as significant. Hasil penelitian Laamiri et al., (2015), research results, stated that the case of breast cancer in a woman is influenced by slow menopause age, too early menopause age, use of pill contraception, and a family history of breast cancer.

The onset of late menopause, every year will have a risk for breast cancer by $3 \%$, and any delay in the onset of menopause age every 5 years will have a greater risk for developing breast cancer, which is 17\% (Ford D et al. 1998 dalam Shah R et al. 2014). The results of this study indicate that there is an influence of family history of breast 
cancer with a positive direct effect obtained with a regression coefficient (b) of 0.11 with asymp.sign (p) is $0.00<0.014$ expressed as significant.

Based on research results Awaliyah et al., (2017) found that a woman who uses a type of hormonal contraception will have a risk of 1.66 times the case of breast cancer, compared to women who do not use hormonal type of contraception and also found that the duration of hormonal contraception use $\geq 5$ years also associated with the case of breast cancer, which is the longer a woman uses hormonal contraception, the more they will be 2.18 times the risk of developing breast cancer. Other research, conducted by Nissa et al., (2017) showed that there is a relationship between hormonal contraceptive use $(\mathrm{p}=0.013 ; \mathrm{OR}=2.81 ; \mathrm{CI} 2.04-3.59)$, type of hormonal contraception $(\mathrm{p}=0.020$; $\mathrm{OR}=2.76$; CI 1.89-3.63), and duration of hormonal contraceptive use $(\mathrm{p}=0.001 ; \mathrm{OR}=$ 9.06; CI 9.10-11.4) with the case of breast cancer.

The results of this study are also in line with the results of research Nissa et al., (2017) which stated that the factors that play a role in the case of breast cancer are exogenous hormonal exposure such as the use of hormonal contraception. Another study that is in line with the results of the above study is the research of Soroush et al., (2016) explained that the use of hormonal contraceptive pill types after more than 4 years can increase the risk of breast cancer 1.52 times.

The estrogen and progesterone hormones contained in hormonal contraception cause hormonal imbalances in the body. The use of hormonal contraception will cause estrogen and progesterone levels to increase in the body. Estrogen plays a role in fat formation, so the more estrogen levels in the body, the more amount of fat in the body. The fat that is formed can cause the estrogen-binding protein SHBG to decrease, so that the amount of estrogen will circulate more in the blood and enter various cells in the body through its receptors. Estrogen receptors are important in the breast gland, so the more use of hormonal contraception, the more estrogen that binds to the receptors in the breast gland which causes CYP17 and CYP19 gene activity to increase so that it can cause splicing mRNA to be disturbed (Lange, 2008).

Progesterone receptors can also be found in the breast glands. Progesterone will bind to the receptor to form the progesterone receptor element complex (PRE) or which together with EGF or heregulin will induce transcription and post-translational activity. When the process continues to occur excessively, there will be an accumulation of genetic errors in the BRCA1, BRCA2, HER2/NEU or p53 genes and atypical hyperplasia occurs with increasing time causing carcinoma of the breast (Yager et al., 2006).

4. Effect of parity and breast cancer case.

The results of hypothesis testing indicate that there is a positive effect of parity on the case of breast cancer that is directly or indirectly. The indirect effect can be explained that first there is a positive influence of parity with menopausal age, where a regression coefficient (b) of 0.48 with asymp.sign (p) is $0.49>0.05$ is declared insignificant. Then, the second age of menopause with the case of breast cancer obtained a positive effect with a regression coefficient (b) of 0.17 with asymp.sign (p) is $0.00<0.05$ otherwise significant. Thus, it can be concluded that there is an indirect and positive effect on the case of breast cancer.

The theory explains that the effect of parity on menopausal age is controlled by $\mathrm{AMH}$ hormone receptors known as AMHR2 - $482 \mathrm{~A}>\mathrm{G}$ polymorphism. Along with 
hormonal changes leading to increased parity, very high levels of progesterone have been shown to increase AMH receptor expression in tissues. Furthermore, high levels of prolactin also potentiate the effect of up regulation of the AMHR2 receptor (Kevenaar et al., 2007). The high number of AMH receptors will ultimately strengthen the inhibitory effect of the initial recruitment process of primordial follicles, thus slowing the case of menopause. Bromberger (1997) explained that several studies have been conducted to prove the theory. A study comparing the age of menopause in nullipara with multipara found nulliparous women potentially experiencing menopause 16 months faster $(\mathrm{p}<0.10)$ compared to multipara. The longer age of menopause causes a longer woman is also exposed to the hormone estrogen which is one of the triggers of breast cancer.

In addition to its indirect effect, parity also has a direct effect on the case of breast cancer. In nulliparous women or not having children, there is a risk of developing breast cancer. Meanwhile, in women who have children 1 or 2 are considered at lower risk of developing breast cancer. The higher the parity of a person or to experience grandemulti, the higher the risk of breast cancer is. Women with a large number of children, have a longer fertility period so that the age of menopause will be longer. Prolonged age of menopause causes long exposure to the estrogen hormone which triggers an increased risk of breast cancer.

5. Effect of History of Tumor and Ca Descendants on Breast Cancer.

The results of data analysis showed that there is a positive influence on the history of tumor and $\mathrm{Ca}$ descent on the quality of life of menopause that is indirectly through the age of menopause. First, there is a positive influence on the history of tumor and ca descendants with menopausal age, where a regression coefficient (b) of 0.31 with asymp.sign (p) is $0.00<0.05$ is significant; then the second age of menopause with the case of breast cancer obtained a positive effect with a regression coefficient (b) of 0.17 with asymp. sign (p) is $0.00<0.05$ otherwise significant.

Age of menopause affects the case of tumors and Ca Sihombing (2014) stated that the age of menopause is one of the factors causing tumors and breast cancer in Bogor Regency. Age at menopause over 55 years at risk 2 times affected by breast cancer compared with women who experience menopause before the age of 45 years. This is due to the longer exposure to the female estrogen hormone which has a chance of developing breast cancer (Irwan, 2015).

In addition to the indirect effect, a history of tumor descent and ca also directly affected the case of breast cancer, where a regression coefficient (b) of 0.17 was obtained with an asymp.sign (p) value of $0.00<0.05$ otherwise significant. It is in line with the theories of William F dan J Christopher (2001), who stated that a positive family history of breast cancer is the biggest risk factor for breast cancer. Women with one person from a family suffering from breast cancer have a two-fold risk of developing breast cancer, and women with 2 people suffering from breast cancer have a 14-fold greater risk of developing breast cancer, while $20 \%$ of women suffering from breast cancer have a distant family history of suffering from breast cancer.

6. Effect of income level on the case of breast cancer.

The results of data analysis show that there is a positive effect on income level on the quality of life of menopause that is indirectly through menopause age and parity. First, there is a positive influence on income level with menopause age, where a 
regression coefficient (b) of 0.14 with asymp.sign (p) is $0.24>0.05$ declared insignificant. The income of respondents in this study has an influence on the age of menopause. This is not in line with research conducted by Diniyati (2016) about the factors that influence the age of menopause. Research results Diniyati (2016) stated that there is no influence of income with menopause age.

The second indirect effect, that is the influence of menopause age with the case of breast cancer obtained a positive effect with a regression coefficient (b) of 0.17 with asymp.sign (p) is $0.00<0.05$ otherwise significant. It has been explained that the longer a woman gets menopause, the longer the risk of exposure to the estrogen hormone is. Long exposure to hormones to a woman can increase the risk of developing breast cancer.

Third, there is a positive influence on the level of income with parity, where a regression coefficient (b) of 0.45 with asymp.sign (p) is $0.00<0.05$ is significant. Income can be interpreted as the sum of all money received by a person or household during a certain period (usually one year) that can be obtained from salaries, wealth or other income. Having children is an additional cost that is sure to reduce one's income. The more children you have, the higher the costs involved. Parents who have high incomes or increased incomes have aspirations for better children, parents want children with good quality so that the costs required are also higher (BKKBN, 2007).

This is not in line with research conducted by Ainiyah (2015) using the product moment correlation test, the results obtained $\mathrm{p}=0.456>\alpha(0.05), \mathrm{r}=0.046$ which means that there is no influence between income and maternal parity. There are other factors that cause the high or low parity of mothers, which are the views of mothers who are different about parity. It causes no effect on family income on the number of children.

Then, the fourth indirect effect of parity with the case of breast cancer obtained a positive effect with a regression coefficient (b) of 0.08 with asymp.sign (p) is 0.03 $<0.05$ otherwise significant. Parity affects the case of breast cancer. It has been explained previously that nulliparous women or children do not have a risk of developing breast cancer. Meanwhile, in women who have children 1 or 2 are considered at lower risk of developing breast cancer. The higher the parity of a person or to experience grandemulti, the higher the risk of breast cancer is. Women with a large number of children, have a longer fertility period so that the age of menopause will be longer. Prolonged age of menopause causes long exposure to the hormone estrogen which triggers an increased risk of breast cancer.

In addition to the indirect effect, the level of income also has a direct effect on the case of breast cancer, where a regression coefficient (b) of 0.41 is obtained with an asymp.sign (p) value of $0.00<0.05$, which is significant. Thus, it can be concluded that there is a direct and positive effect on income level on breast cancer case. Women with low socioeconomic/income levels affect access to early detection, so there is a risk of having a late diagnosis and treatment of cancer (Ward et al., 2004). Women who are blue-collar workers (low socioeconomic) have a risk 4 times higher than women who are light workers or office workers (socioeconomic middle to upper).

This is in line with research conducted by Yulianti (2016) about factors related to the case of breast cancer which stated that there is a relationship between a woman's income level and the case of breast cancer. The effect of increased income on improving health and other family conditions that interact with the case of breast cancer is almost universally opposite, economists argue that with an improvement in the economy, the 
rate of breast cancer will decrease, with a note that only economic factors are determinants of cancer case breast. In fact the case of breast cancer is complex, because not only economic factors play a role but other factors also determine.

\section{CONCLUSION}

Based on the results of this study, it can be concluded that the case of breast cancer is directly affected by hereditary cancer, family planning history, age, parity, age of menopause and income. In addition, breast cancer is also indirectly affected by income through parity; and hereditary history of breast cancer, family planning history $(\mathrm{KB})$, and age through menopause. It is recommended for further researchers, is expected to conduct research with different variables and methods, so that factors that influence the case of breast cancer can be identified.

\section{REFERENCES}

Ainiyah, A. (2015). Pengaruh Faktor Pendidikan Ibu, Pendapatan Keluarga, Demografi, Pengetahuan dan Perilaku Ibu terhadap Paritas di Kecamatan Laren Kabupaten Lamongan. Swara Bhumi, 1(1).215-224.

American Cancer Society. (2015). Breast Cancer Facts \& Figures 2015-2016. Atlanta: American Cancer Society

Anggorowati, L. (2013). Faktor risiko kanker payudara wanita. KEMAS: Jurnal Kesehatan Masyarakat, 8(2).121-126

Awaliyah, N., Pradjatmo, H., \& Kusnanto, H. (2017). Penggunaan Kontrasepsi Hormonal dan Kejadian Kanker Payudara Di Rumah Sakit Dr. Sardjito. Berita Kedokteran Masyarakat. 33(10), 487-494.

Bentzen, J. G., Forman, J. L., Pinborg, A., Lidegaard, O., Larsen, E. C., Friis-Hansen, L., \& Andersen, A. N. (2012). Ovarian Reserve Parameters: A Comparison Between Users And Non-Users Of Hormonal Contraception. Reproductive biomedicine online, 25(6), 612-619.

BKKBN. (2007). Keluarga Berencana dan Kontrasepsi. Cetakan ke-5. Jakarta : Pustaka Sinar Harapan

Bromberger, J. T., Matthews, K. A., Kuller, L. H., Wing, R. R., Meilahn, E. N., \& Plantinga, P. (1997). Prospective Study of The Determinants of Age At Menopause. American journal of epidemiology, 145(2), 124-133.

Diniyati, D., \& Heriyani, N. (2016). Faktor-Faktor yang Memengaruhi Usia Menopause di Kelurahan Buluran Kenali Kota Jambi Tahun 2015. Jurnal Ilmiah Universitas Batanghari Jambi, 16(2), 24-30.

Fitriyani, F., \& Djuwita, R. (2013). Hubungan Penggunaan Kontrasepsi Pil dengan Usia Menopause. Kesmas: National Public Health Journal, 8(4), 187-192.

Fitzmaurice, C., Dicker, D., Pain, A., Hamavid, H., Moradi-Lakeh, M., MacIntyre, M. F., \& Hamadeh, R. R. (2015). The global burden of cancer 2013. JAMA oncology, 1(4), 505-527.

Irwan, I., Azamris, A., \& Bachtiar, H. (2015). Perbandingan Prognosis Subtipe Molekuler Kanker Payudara Antara Pasien Kanker Payudara Wanita Usia Muda dan Tua di RSUP DR. M. DJAMIL PADANG. Majalah Kedokteran Andalas, 38(3), 208-217.

Kallel, M., Elloumi, F., Khabir, A., Ghorbal, L., Chaabouni, S., Amouri, H., ... \& Daoud, J. (2015). Breast cancer in young women in southern Tunisia: 
Sari, N. I. Y., Maringga, E. G., \& Astuti, W. W. (2019). Path Analysis of the Effect of Biological and Social Factors on the Case of Breast Cancer. JURNAL INFO KESEHATAN, 17(2), 88-100. https://doi.org/10.31965/infokes.Vol17.Iss2.292

Anatomical study and clinical prognostic factors: About a series of 83 patients. Reports of Practical Oncology \& Radiotherapy, 20(3), 155-160.

Kemenkes RI. (2015). Situasi Penyakit Kanker. Jakarta: Kementerian Kesehatan RI.

Kemenkes RI. (2017). Panduan Penatalaksanaan kanker Payudara. Jakarta: Komite Penanggulangan Kanker Nasional Kementerian Kesehatan Republik Indonesia.

Kevenaar, M. E., Themmen, A. P., Rivadeneira, F., Uitterlinden, A. G., Laven, J. S., van Schoor, N. M., \& Visser, J. A. (2007). A polymorphism in the AMH type II receptor gene is associated with age at menopause in interaction with parity. Human reproduction, 22(9), 2382-2388.

Laamiri, F. Z., Bouayad, A., Hasswane, N., Ahid, S., Mrabet, M., \& Amina, B. (2015). Risk Factors for Breast Cancer of Different Age Groups: Moroccan Data?. Open Journal of Obstetrics and Gynecology, 5(02), 79-87.

Lange CA, Yee D. (2008). Progesterone and Breast Cancer. Womens Health (Lond) ; $4(2): 151-62$.

Listyawardhani, Y., Mudigdo, A., \& Adriani, R. B. (2018). Risk Factors of Breast Cancer in Women at Dr. Moewardi Hospital, Surakarta, Central Java. Journal of Epidemiology and Public Health, 3(2), 118-127.

Maringga, E. G., Adriani, R. B., \& Mudigdo, A. (2017). Effect of Contraceptive Use, Parity, and Social Economic Factors on Age at Menopause at Bendo Community Health Center, Kediri, East Java. Journal of Maternal and Child Health, 2(2), 113-124.

Nissa, P. A. E., Widjajanegara , H., \& Purbaningsih, W. (2017). Kontrasepsi Hormonal sebagai Faktor Risiko Kanker Payudara di RSUD Al-Ihsan Bandung. In Bandung Meeting on Global Medicine \& Health (BaMGMH), 1(1),112-119.

Rasjidi (2010). Deteksi Dini dan Pencegahan Kanker pada Wanita. Jakarta: Sagung Seto

Shah, R., Rosso, K., \& Nathanson, S. D. (2014). Pathogenesis, prevention, diagnosis and treatment of breast cancer. World journal of clinical oncology, 5(3), 283298.

Sihombing, M., \& Sapardin, A. (2014). Faktor Risiko Tumor Payudara Pada Perempuan Umur 25-65 Tahun Di Lima Kelurahan Kecamatan Bogor Tengah. Jurnal Kesehatan Reproduksi, 5(3), 175-184.

Soroush, A., Farshchian, N., Komasi, S., Izadi, N., Amirifard, N., \& Shahmohammadi, A. (2016). The role of oral contraceptive pills on increased risk of breast cancer in Iranian populations: a meta-analysis. Journal of cancer prevention, 21(4), 294-301.

Suparman, E., \& Suparman, E. (2014). Peran estrogen dan progesteron terhadap kanker payudara. Jurnal Biomedik, 6(3). 141-148

Ward, E., Jemal, A., Cokkinides, V., Singh, G. K., Cardinez, C., Ghafoor, A., \& Thun, M. (2004). Cancer disparities by race/ethnicity and socioeconomic status. $C A: a$ cancer journal for clinicians, 54(2), 78-93.

WHO. (2013). Global Cancer Burden Rises To 14.1 Million New Cases In 2012: Marked Increase In Breast Cancers Must Be Addressed. Geneva: International Agency for Research on Cancer.

WHO. (2018). Breast Cancer : Prevention and Control. Geneva

William F. R., \& Christopher. (2001). Obstetri dan Ginekologi. Jakarta: Widya Medika. 
Yager, J. D., \& Davidson, N. E. (2006). Estrogen Carcinogenesis In Breast Cancer. New England Journal of Medicine, 354(3), 270-282.

Yulianti, I., Santoso, H. S., \& Sutinigsih, D. (2016). Faktor-Faktor Risiko Kanker Payudara (Studi Kasus Pada Rumah Sakit Ken Saras Semarang). Jurnal Kesehatan Masyarakat (e-Journal), 4(4), 401-409. 